\title{
Correlation Between Family Support and Quality of Life: People Living With Tuberculosis in Surabaya
}

\author{
$1^{\text {st }}$ Nur Mukarromah \\ Faculty of Health Sciences \\ Universitas Muhammadiyah of Surabaya \\ Surabaya, Indonesia \\ nurmazakaria@gmail.com
}

\author{
$2^{\text {nd }}$ Fatin Lailatul Badriyah \\ Faculty of Health Sciences \\ Universitas Muhammadiyah of Surabaya \\ Surabaya, Indonesia \\ fatinchasani@gmail.com
}

\begin{abstract}
Tuberculosis is a disease that affect the physical and psychological health, social relationship and environment of people living with tuberculosis. The treatment take longterm process, and this situation is not easy situation for people living with tuberculosis. Involvement of patient's family is needed to support the process. Therefore, this study aim was to identification the correlation between family support and quality of life people living with tuberculosis in Surabaya. Descriptive correlation cross-sectional design was used. Eighty five people living with tuberculosis were wailing to participate in this study. Simple random sampling was perform to identify the participants. World health organization quality of life and family support questionnaires were used to collect the data. Both of questionnaires were achieved a good grade of validity and reliability test. Reliability score of quality of life questionnaire was $0.65-0.82$ and the reliability score of family support questionnaire was 0.82 . Descriptive statistic and spearmen's rho test was used to analyze the data. The mean score for quality of life variable was $\mathbf{8 3 . 7 6}$ and for the family support variable was 98.93 . There was significant correlation between family support and quality of life people living with tuberculosis (rho 0.304). In sum, one of element to achieved succeed of medication program of people living with tuberculosis is family involvement to support tuberculosis patients.
\end{abstract}

\section{Keywords-Quality of Life, Family Support, Tuberculosis}

\section{INTRODUCTION}

Tuberculosis is an infectious disease caused by tuberculosis Mycobacterium and is contagious [1]. Most of the Mycobacterium tuberculosis bacteria attack the lungs, but can also attack other organs [2]. Pulmonary TB itself is a chronic (chronic) disease that has long been recognized by the wider community and feared for being contagious [3]. TB or tuberculosis is transmitted through a variety of ways, one of which is through air or mucus or sputum sufferers [1].The World Health Organization states that one third of the world's population has been infected with tuberculosis bacteria and in every second there is one person infected with tuberculosis [1]. The World Health Organization also stated that TB is second only to HIV and AIDS as the biggest killer in the world because of a single infectious agent [2]. Based on the 2013 World Health Organization report, Indonesia is a country that ranks third in the number of cases of tuberculosis after India and China with a total of 700 thousand cases. The mortality rate is still the same as in
2011 of 27 per 100,000 population, but the incidence rate dropped to 185 per 100,000 population in 2012[1].

Although the incidence rate has decreased, but the number of TB sufferers is still very much even felt to rival the high incidence of non-communicable diseases such as coronary heart disease which is still the main cause of death. The high incidence of TB is certainly inseparable from the ease of transmission of this disease and the length of treatment that must be followed by TB patients. The period of treatment has a very important role for healing TB patients. Therefore TB sufferers need special support from their families in maintaining their health status, especially in undergoing a long series of TB treatments.Family support is considered important because patients who get family support tend to be easier to change their behavior towards healthier than those who lack support [3]. Family support for TB patients is expected to help achieve the completeness of TB treatment so that events such as drug withdrawal, resistance to TB drugs can be resolved and can stabilize and improve the quality of life of TB patients themselves.Quality of life is the individual's perception of his position in the context of culture and the value system in the place where the individual lives and his relationship to his goals, hopes, standards and focus of life[3]. Living a life with a disease is not easy, especially if the disease is an infectious disease like TB, it is certainly feared by the general public where this can make TB sufferers feel inferior. With these conditions, it can affect the welfare of TB patients which will have an adverse impact on the quality of life.Family support has 4 dimensions of support namely emotional support, reward support, instrumental support and informative support[3].

Four dimensions in family support is important for the quality of life of TB patients with a variety of complicated conditions such as the response of the wider community to the spread of TB disease and the long treatment period that must be followed.Quality of life needs to get special attention from the community because the quality of life can be used as a reference for the success of a patient's health care. As is well known, TB disease is not a trivial disease because in addition to being easily contagious, the treatment period is also long. Where if this [4]disease is not treated properly, it can cause various adverse effects that affect the quality of life, especially for patients themselves and others such as drug resistance, recurrent TB, transmission of TB to the surrounding environment, and so forth.Low quality of life can worsen health conditions and can end disability or 
death. Quality of life affects physical health, psychological conditions, and level of dependence, social relationships and patient relationships to the surrounding environment [3].Based on the above phenomenon, researchers feel interested in knowing "The Relationship of Family Support to the Quality of Life of Patients with TB in Semampir Subdistrict".

\section{RESEARCH METHODS}

Analytic correlation cross-sectional design was used in this study. Eighty five people who living with tuberculosis were willing to participate in this study. Simple random sampling was used to select the participants. The data were collected using quality of life and family support questionnaires. The World Health Organization Quality of Life Brefquestionnaire was used. There were twenty six questions in World Health Organization Quality of Life questionnaire described about four domains which are physical health (Q3, Q4, Q10, Q15, Q16, Q17, Q18), Psychological (Q5, Q6, Q7, Q11, Q19, Q26), Social Relationship(Q20, Q21, Q22), and environment (Q8, Q9, Q12, Q13, Q14, Q23,Q24, Q25). Value of validity and reliability tests for World Health Organization Quality of Life Questionnaire were 0.97 and 0.65-0.82[5].

Family Support Questionnaire was adopted from family support questionnaire which was developed by Biswas [6]. This questionnaire developed based on House (1981) Family Support Questionnaire and related literature [6]. There were four support items which are emotional support (Q1, Q2, Q3, Q4, Q5, Q6, Q7, Q8, Q9, Q10), instrumental support (Q11, Q12, Q13, Q14, Q15, Q16, Q17, Q18, Q19), Informational support (Q20, Q21, Q22, Q23, Q24, Q25, Q26) and Appraisal Support (Q27, Q28, Q29, Q30, Q31, Q32, Q33).

Value of reliability tests for family support questionnaire was 0.82 . Descriptive statistic and spearmen's rho test was used to analyze the data. Descriptive statistic was mean value. Spearmen's rho test was used to analyze the correlation between family support and quality of life people living with tuberculosis in Surabaya.

\section{RESULTS AND DISCUSSION}

The World Health Organization Quality of life was measured based on the 4 domains of Quality of life. The highest mean between four domains of quality of life was Psychological domain (69.5059) and the lowest mean between four domains of quality of life was physical health domain (61.8588) (Table 1). The results of this study based on the table 1 , there were some participants had mean score below of mean score in each domains. Physical health, Psychological, social relationship and environments domains of quality of life were affected by tuberculosis [7]. Long-term treatment was needed to cure the tuberculosis disease [8].
Tuberculosis is a disease that firstly will attack the patient's physical health. By the time, this disease will affect patient's psychological health. Their psychological health was disturbed by social relationship situation and their life environmental as well. Therefore, succeed of tuberculosis treatment is not just depend on patients, but also the external factors of patients such as their family involvement during medication program.

Therefore, people living with tuberculosis needed their family or their closer friend to provide support during treatment program [9]. Another study reported that psychological condition of people living with tuberculosis will affect their self-efficacy [4]. This study suggested to involve nurse as health care provider to accompany people living with tuberculosis and their family during treatment process.

Based on the table 2, Family Support was measured based on the four domains of Family Support. The highest mean between four domains of Family Support was Appraisal Support domain (80.0235) (Table 2). There were two domains which had same score on the family support variable. Those domains were the lowest mean between four domains of Family Support which is Emotional Support and Informational Support domains (75.8588) (Table 2). The mean score for quality of life variable was 83.76 (table 1) and for the family support variable was 98.93 (table 2). A study showed that family who get involvement in medication program of tuberculosis patient have important role in the succeed treatment [8]. Appraisal support is one of important support that needed by adults to solve about matters during treatment.

The statistic correlation test between Family Support and Quality of life showed that there was significant correlation between both variables (rho 0.004). However, the correlation Coefficient was 0.306 (Table 3). Study showed that disease progression was affected by family support [9]. It means that patient condition is getting better maybe due to family support.

In this term, we can said that a better condition indicated a better quality of life of the patient. The family support include their family involvement in medication program choice, recovery process [9]. A study emphasize that the role of family member in tuberculosis treatment is influence by their prior knowledge about tuberculosis and treatment medication [10].

Our study resulted showed that the mean score of appraisal support from family was in the highest level compare with the other domains. Prior knowledge about tuberculosis will lead the effectiveness of appraisal support. Instrumental support is also has special role in enhance the quality of live people living with tuberculosis. This support will address the needs of people living with 
tuberculosis[10]. A qualitative study found that lack of family support will has negative effect to the cure process of people living with tuberculosis [11].Therefore, it is important to educated family member of people living with Tuberculosis about the disease, prognosis, and medication as well.

Table 1 Quality of life Among People Living with Tuberculosis in Surabaya

\begin{tabular}{|l|c|r|r|c|c|}
\hline Quality of Life Domains & N & Minimum & Maximum & Mean & SD \\
\hline PhysicalHealth & 85 & 31.00 & 89.00 & 61.8588 & 12.01403 \\
Psychological & 85 & 47.00 & 93.00 & 69.5059 & 11.84184 \\
SocialRelationship & 85 & 20.00 & 100.00 & 64.2588 & 16.40496 \\
Environment & 85 & 40.00 & 95.00 & 65.0294 & 10.62408 \\
Mean Score & & & 83.76 & & \\
\hline
\end{tabular}

Table 2 Family Support among Living with tuberculosis in Surabaya

\begin{tabular}{|l|c|c|c|c|c|}
\hline Family Support Domains & $\mathbf{N}$ & Minimum & Maximum & Mean & SD \\
\hline EmotionalSupport & 85 & 39.00 & 100.00 & 75.8588 & 14.89259 \\
InstrumentalSupport & 85 & 44.00 & 203.00 & 79.0706 & 19.86789 \\
InformationalSupport & 85 & 39.00 & 100.00 & 75.8588 & 14.89259 \\
AppraisalSupport & 85 & 50.00 & 100.00 & 80.0235 & 14.76561 \\
Mean Score & & & & 98.93 & \\
\hline
\end{tabular}

Table 3 Analysis Correlation Spearmen's Rho

\begin{tabular}{|c|c|r|}
\hline \multicolumn{2}{|c|}{} & Family Support \\
\hline Quality Of Life & Correlation Coefficient & $0.306^{* *}$ \\
& Sig. (2-tailed) & 0.004 \\
& $\mathrm{~N}$ & 85 \\
\hline
\end{tabular}

\section{ONCLUSION}

Family support is one of key point in the recuperation tuberculosis's patients. One of the important involvement of family who has family member with tuberculosis is in companion during taking tuberculosis medication. Family roles is include the ability to provide appraisal support. Family provide a better direction to get a good treatment.

\section{ACKNOWLEDGEMENT}

This study was funded by Indonesia ministry of research and technology. During the research process, the researchers were helped by people in Aisyiyah organization in
Surabaya. All of the participants were so amazing, the willing to participated and fully support this study.

\section{REFERENCES}

[1] Suharyo, "Determinasi Penyakit Tuberkulosis Di Daerah Pedesaan,” J. Kesehat. Masy., vol. 9, pp. 85-91, 2013.

and D. S. A. R. M. Putri, Wahiduddin, "Hubungan Dukungan Sosial Dengan Kualitas Hidup Pada Penderita TB Paru di BBKPM Kota Makassar,” J. Univ. Hasanuddin, 2012.

[3] I. R. Ningrum, "Hubungan Dukungan Keluarga Dan Tingkat Pengetahuan Dengan Kualitas Hidup Pasien Dm Tipe 2 Di Puskesmas Nogosari Boyolali,” vol. 2018.

and J. M. F. C. A. Marra, F, Marra1 V. C. Cox, A. Palepu, "Factors Influencing Quality of Life in Patients with Active Tuberculosis," Health Qual. Life Outcomes, vol. 2, no. 58, 2004.

Y. W. and S. H. Saputra, "The Association Between Stigma and Quality of Life People Living with HIV/AIDS in Surabaya," vol. 5, no. 3, 2017.

B. R. Biswas, "The Relation between family support and health behaviours among patient with pulmonary tuberculosis," Prince Songkla Univ., 2010.

and G. B. D. N. N. Hansel, A. W. Wu, B. Chang, "Quality of life in tuberculosis: Patient and provider perspectives," Qual. Life Res, vol. 13, no. 3, pp. 639-652, 2004.

[8] T. H. and I. N. Pratiwi, "Family Coping Affects The Quality of Life Patients with Tuberculosis," Adv. Heal. Sci. Res., vol. 3, 2017.

H. I. D, "Hubungan Dukungan Sosial dengan Kualitas Hidup pada Penderita Tuberkulosis Paru di Balai Kesehatan kerja Masyarakat Provinsi Jawa Barat Tahun 2014,” J. Bhakti Kencana Med., vol. 4, no. 1, pp. 58-63, 2014.

[10] and R. A. A. I. M. Freitas, J. D. A Crispim, I. C Pinto, T. C. S. Villa, M. E. F. Brunello, P. F. P. S. Pinto, "Knowledge And Perception About Tuberculosis Of Patients' Families Under Directly Observed Treatment At A Health Service In Ribeirão Preto-Sp Brazil," Text Context Nurs., vol. 21, no. 3, p. 642.

[11] O. A. A. A. and H. P. Martine, "Barriers Leading to Treatment Default Among Tuberculosis Patients in Khartoum State: A Qualitative Study," Clin. Med. Investig., vol. 3, no. 1, 2018. 